\title{
EPIDEMIOLOGY OF ESOPHAGEAL CANCER, RISK FACTORS AND POSSIBILITIES FOR PREVENTION
}

\author{
Milica Bjelaković1 , Daniela Benedeto Stojanov ${ }^{1}$, Ivana Golubović2 \\ Marko Bjelaković3 ${ }^{3}$ Marko Gmijović ${ }^{4}$
}

\begin{abstract}
The incidence and mortality of esophageal cancer in developed countries increased in the last four decades, as opposed to the reduced incidence and mortality of other cancers. Esophageal cancer is the eighth most common and the sixth leading cause of cancer death in the world. In the last 3 decades, there has been a shift in the leading histological type of esophageal cancer in developed countries from esophageal squamous cell to esophageal adenocarcinoma. Risk factors lead to the appearance of precancerous conditions, squamous dysplasia as a precursor of esophageal squamous cell carcinoma and Barrett's esophagus as a precursor of esophageal adenocarcinoma. Tobacco, alcohol, hot Mate drink and pickled vegetables are associated with increased risk of esophageal cancer, while increased fruit and vegetable intake could have a preventive effect on esophageal cancer. The evidence about the influence of distal esophageal sphincter relaxants and histamine 2 receptor antagonists is contradictory. There is an inverse association of Helicobacter pylori infection and Barrett's esophagus and esophageal adenocarcinoma. We have low certainty evidence about the effect of infection with human papilloma virus and different chemical carcinogens like polycyclic aromatic hydrocarbons, N-nitroso compounds, acetaldehyde, and fumonisins on esophageal cancer. A number of predisposing conditions like gastro-esophageal reflux disease, Barrett's esophagus, obesity, hiatal hernia, achalasia, tylosis, and Plummer Vinson syndrome may increase the risk of esophageal cancer. Primary prevention of esophageal cancer consists of lifestyle changes like smoking cessation, stopping of alcohol consumption and increased intake of fruits and vegetables. Secondary prevention consists of chemoprevention, screening and monitoring program.
\end{abstract}

Acta Medica Medianae 2021;60(4):72-81.

Key words: esophageal cancer, risk, prevention

\footnotetext{
${ }^{1}$ University Clinical Center Niš, Clinic of Gastroenterology and Hepatology, Niš, Serbia

${ }^{2}$ University Clinical Center Niš, Clinic of Hematology and Clinical Immunology, Niš, Serbia

${ }^{3}$ University Clinical Center Niš, Clinic of Pulmonology, Niš, Serbia

${ }^{4}$ University Clinical Center Niš, Clinic for Digestive Surgery, Niš, Serbia
}

Contact: Milica Bjelaković

48 Dr Zoran Djindjić Blvd., 18000 Niš, Serbia

E-mail: milicabj@icloud.com gical papyrus" written by Edwin Smith reparation of the esophagus after perforation is described, but without a clear emphasis on cancer (1). Galen, 125200 AD, a well-known physician and philosopher of the Roman Empire, published a paper on the causes and symptoms of esophageal cancer, pointing out the possibility that meaty growths partially or completely obstruct the passage of food through the esophagus (1). Avicenna, who is considered the father of modern medicine, in one of the papers entitled "Canon of Medicine" published in 1025, pointed out that dysphagia is the most significant symptom of esophageal tumors (2). Earliest evidence came also from some areas of China which are characterized by a high incidence of esophageal cancer. As the main symptom in patients, "Ye Ge" is mentioned, which means dysphagia and belching. Dysphagia syndrome was reported among the inhabitants of Henan Province 2000 years ago. Additionally, a condition called "ge shi bing" has been described in Linxian Province. Arab clinician Avenzoar (1090-1162) gave some very useful advice regarding the treatment of patients with esophageal cancer (2). He recommended "injecting food into the cancer was collected during the $19^{\text {th }}$ and 20 century, the first data related to the disease came from Egypt around 3000-2500 BC. In a "Smith sur- 
stomach through a silver tube as well as using nutrient solutions". One of the leading physicians of the $16^{\text {th }}$ century, the Frenchman Jean Francois Fernel (1497-1558) described scirus and other tumors that block the esophagus causing dysphagia. Surgeon John Casaubon, who died of esophageal cancer in 1691, was the first who correctly described the symptoms of the disease (2).

\section{Epidemiology}

In developed countries, the incidence and mortality of esophageal cancer increased in the last three decades, as opposed to the reduced incidence and mortality of other cancers. Between 1973 and 2020 , the incidence rate of the most common cancers including breast, colon, and lung was stable or decreased in the United States. There has been an increase in prostate cancer and melanoma, but this is small compared to the $600 \%$ increase in the incidence of esophageal adenocarcinoma (EAC) in the same period. The risk of developing esophageal cancer increases with age and is greatest in the seventh decade of life. The prognosis is generally poor. The 5 -year survival rate ranges between 10 and $13 \%$, and only 1 in 5 patients survives 3 years or more (3). Therefore, the esophageal cancer prevention strategy must take into account its changing epidemiology. Esophageal cancer is the eighth most common and the sixth leading cause of cancer death in the world $(4,5)$. The average incidence in the world is 11.5 cases per 100,000 in men and 4.7 per 100,000 in women (6). There are large geographical variations in the world in terms of incidence and mortality from esophageal cancer. The incidence, as well as mortality, can vary from one part of the world to another up to 500 times (7). It is known that Asian countries, especially China, India, Pakistan, and Japan, have the highest rates of esophageal cancer in the world (8). Asian belt of esophageal cancer (the region with the highest incidence rate of esophageal cancer in the world) originates from Turkey, goes through Iraq, Iran and Kazakhstan and ends in North China. The incidence of esophageal cancer in this zone is 100 cases per 100,000 inhabitants. The incidence is equal in men and women and is more common in people of Turkish and/or Mongolian descent than those of Indo-European descent. Most frequent histological type in the Asian belt is esophageal squamocellular cancer. The overall incidence rate is twice as high in less developed countries then in developed countries with the highest incidence rates in Asia (9). The highest EC incidence rates in the standard age structure population were recorded in China, South and East Africa, and Japan. More than $90 \%$ of esophageal cancers are either squamous cell carcinomas (SCC) or adenocarcinomas (AC). Other cancers, melanomas, leiomyosarcomas, carcinoids and lymphomas occur less frequently in the esophagus.

The epidemiology of the two histological types of esophageal cancer (squamous cell and adenocarcinoma) differs significantly. The most common histological type in the world is esophageal squamous cell carcinoma (ESCC) while in the USA and Europe, esophageal adenocarcinoma (EAC) currently predominates (10).

In the last four decades, there has been a shift in the leading histological type of esophageal cancer in developed countries from esophageal squamous cell to esophageal adenocarcinoma (11, 12). In developed countries, esophageal squamous cell carcinoma occurs three to four times more often in men than in women, while in the Asian belt of esophageal cancer the incidence is the same among men and women (13).

The risk of developing of esophageal cancer increases with age. On average, EAC is formed ten years earlier than ESCC, on average at the age of 53 (11).

\section{Risk factors}

Craver (14) and Watson (15), dealing with the problem of risk factors for the development of esophageal cancer listed excessive use of alcohol and tobacco, low socioeconomic status, poor oral hygiene and consumption of hot beverages as one of the main ones. Craver also quoted an article from Argentina that pointed out that consuming Mate drink, consumed in larger quantities in South America, as an additional risk factor (Table 1) (14).

Table 1. Risk factors for esophageal cancer

\begin{tabular}{||l||l||}
\hline \hline Habits & tobacco, alcohol, hot drinks, mate drinks, pickles \\
\hline Nutritional deficiencies & $\begin{array}{l}\text { insufficient intake of fruits and vegetables, deficiency of } \\
\text { vitamins and minerals }\end{array}$ \\
\hline Medicines & $\begin{array}{l}\text { relaxing the lower esophageal sphincter, histamine 2 } \\
\text { receptor antagonists }\end{array}$ \\
\hline Infections & Helicobacter pylori, human papillomavirus \\
\hline Chemical & $\begin{array}{l}\text { polycyclic aromatic hydrocarbons, nitrosamines, } \\
\text { acetaldehyde }\end{array}$ \\
\hline Physiological or pathological predisposing conditions & $\begin{array}{l}\text { gastroesophageal acid reflux, hiatal hernia, achalasia, } \\
\text { tylose }\end{array}$ \\
\hline Occupational exposure & silicone and asbestos \\
\hline Low socioeconomic status & \\
\hline
\end{tabular}


Risk factors lead to the appearance of precancerous conditions, squamous dysplasia as a precursor of esophageal squamous cell carcinoma and Barrett's esophagus as a precursor of esophageal adenocarcinoma.

\section{Habits}

\section{Tobacco}

Current and former smokers are at higher risk for developing esophageal cancer (EC). Smoking significantly increases the risk of developing ESCC and less of developing EAC. Active smokers have a 3 to 7 times higher risk of developing ESCC and about 2 times higher risk of developing EAC (16). The risk of developing EC is directly correlated with the number of cigarettes smoked as well as the length of smoking experience $(17,18)$. The risk persists for 30 years after smoking cessation (19).

\section{Alcohol}

Continuous alcohol intake significantly increases the risk of developing ESCC but not EAC (17, 18) although there are observational studies that suggest a possible link between alcohol and EAC. Exposure to tobacco and alcohol has a synergistic effect on the risk of developing EC. The International Agency for Research on Cancer (IARC) classified alcohol as a known cause of EC (20).

\section{Mate}

The hot Mate drink, which is an extract of the herb Ilex paraguayensis, and which is characteristic of the countries of South America, is considered a potential risk factor for the formation of EC. The carcinogenicity of mate beverage is considered to be a consequence of repeated thermal damage and exposure to polyaromatic cyclic hydrocarbons. The first study conducted in Uruguay (21) found a relative risk of 12.2 for those who drank 2.5 I of mate beverage per day, and the risk was even higher, 22.6 for those who consumed alcohol and smoked. Another study (22) found a risk of 2.8 in people who drank more than 1 liter of mate per day, and the risk was even higher (7.1) in those who drank alcohol and smoked at the same time. In 1991, the IARC classified the hot mate beverage as a probable carcinogen for humans (Group 2A) (20).

\section{Pickled vegetables}

Environmental studies have indicated an increased risk of EC in areas where higher amounts of pickles are used in the diet. It is assumed that fungi and yeasts that grow in pickles can release carcinogens (23). Results of epidemiological studies are not consistent. While some of them indicated a significant increase in the incidence of EC in others, the consumption of pickled vegetables did not affect the incidence of EC. The IARC concluded in 1993 that pickles were probably carcinogenic to humans (Group 2B) (24).

\section{Nutrition deficits}

\section{Fruits and vegetables}

The World Cancer Research Foundation (WCRF-AICR) announced in 2016 that there was evidence, although mostly from observational studies, that increased fruit and vegetable intake could have a preventive effect on esophageal cancer (25). Combining all the evidence, it was concluded that the risk of developing EC is reduced by about $20 \%$ for every $50 \mathrm{~g}$ of fruit and vegetables consumed daily (25). The results of recently completed cohort studies support this view $(26,27)$.

\section{Vitamin and mineral deficiency}

Some areas with a very high incidence of EC, such as Linxian, China, are characterized by a large deficiency of vitamins and minerals in the diet. However, two large randomized controlled clinical trials $(28,29)$ and a Cochrane systematic review (30) have failed to demonstrate a reduction in the incidence of EC after vitamin and mineral supplementation over 5 to 6 years.

\section{Medicines}

\section{Distal esophageal sphincter relaxants (DES)}

Asthma medications ( $\beta$-adrenergic agonists and theophylline-containing drugs), calcium antagonists, nitroglycerin, and benzodiazepines relax the lower esophageal sphincter and increase acid reflux. Therefore, they can increase the risk of developing $\mathrm{BE}$ and EAC. Observational studies, however, have yielded contradictory results $(31,32)$. Some of them indicate that medications that lead to DES relaxation contribute to the formation of about $10 \%$ of all EACs $(31,32)$.

\section{Histamine 2 receptor antagonists}

$\mathrm{H} 2$ blockers can reduce EAC risk by reducing the acidic content of gastroesophageal reflux. However, they may increase EAC risk by neutralizing gastric $\mathrm{pH}$, which allows bacteria to proliferate in the stomach which may result in increased production of carcinogens such as nitrosamines and acetaldehyde (12). One study examined the association of $\mathrm{H} 2$ blockers and ESCC, finding no association (33). Another recent study revealed possible increased risk of esophageal cancer after $\mathrm{H} 2$ antagonists (25).

\section{Infections}

\section{Helicobacter pylori infection}

Results of 3 recently published meta-analyses have indicated that gastric colonization with Helicobacter pylori is associated with about a $50 \%$ reduction in the risk of developing EAC (34-36). One meta-analysis indicated an inverse association of $\mathrm{H}$. pylori and $\mathrm{BE}$ (37). There is no association of Helicobacter pylori with ESCC. 


\section{Human papillomavirus}

Oncogenic types of HPV, most commonly HPV 16 and HPV 18, are the causes of cervical cancer, and may play a significant role in the development of epithelial cancers of the vulva, anus, penis, and oropharyngeal cavity. The role of HPV in the development of EC is controversial. Despite the fact that the association of HPV and esophageal tumors has not been established in most studies, there are also studies that found this association in about $75 \%$ of cases. In 2006, the IARC concluded that there was insufficient evidence to indicate carcinogenicity of HPV in the esophagus (38).

\section{Chemical carcinogens}

\section{Polycyclic aromatic hydrocarbons}

Polycyclic aromatic hydrocarbons (PAHs) are formed during incomplete roasting of organic substances. The main sources of PAHs are smoking and air pollution. The causal link between PAHs or substances containing PAHs and cancer has been established for skin, lung and bladder cancers. However, the facts indicating the association of PAHs or substances containing PAHs and EC are based solely on environmental studies (39).

\section{N-Nitroso compounds (NNC)}

NNCs are potent animal carcinogens that can affect the development of cancers of the nasal cavity, esophagus and stomach. Their role in developing cancer in humans has not been established with certainty. A recent umbrella review of 72 metaanalyses examining the association of nitrosamines and EC found that consumption of processed meat, the main source of nitrite and nitrosamines, was associated with a higher risk of developing EC (40).

\section{Acetaldehyde}

Ethanol is converted to acetaldehyde by alcohol dehydrogenase and then to acetate by acetaldehyde dehydrogenase. In 1999, the IARC classified acetaldehyde as carcinogen for animals and a possible carcinogen for humans, mostly because there was insufficient evidence from human studies at the time (41).

\section{Fumonisins}

Fumonisins are toxins secreted by the fungus Fusarium verticillioides (formerly Fusarium moniliforme), which grows mainly on maize. Evidence for the carcinogenicity of fumonisin in humans is uncertain and has mainly come from environmental studies. An observational study indicated no link between fumonisin exposure and EC (42).

\section{Predisposing conditions}

\section{Gastroesophageal reflux disease (GERD)}

Symptomatic GE reflux is perhaps the strongest risk factor for developing EAC (43). People with recurrent reflux symptoms have 8 time higher risk of developing EAC (43). In contrast to EAC, acid reflux is not considered a risk factor for the development of ESCC (43).

\section{Barrett's esophagus}

Barrett's esophagus (BE) is considered to be one of the most significant risk factors for the development of EAC. Patients with BE have 40 times higher risk of developing EAC (44). There is no association of BE and ESCC (44). The overall risk of developing cancer in a patient with $\mathrm{BE}$ is about $0.5 \%$ per year. However, most patients with BE will not develop EAC.

Obesity

Previous epidemiological studies have indicated that a higher body mass index increases the risk of developing EAC. A recently published meta-analysis of 22 case-control and cohort studies found that the risk of EC was significantly higher in obese patients (45). Obesity also increases the risk of developing gastroesophageal reflux disease (46), and Barrett's esophagus (47) that are primary risk factors for EAC. The trend is the opposite for ESCC. Progressively higher BMI is associated with progressively lower risk for ESCC (48).

\section{Hiatal hernia}

Hiatal hernia may increase the risk for developing EAC due to increased GE acid reflux. Numerous studies have found an increased risk, with relative risk ranging from 2 to 6 times (49).

In contrast to EAC, the risk of developing ESCC is not increased in the presence of a hiatal hernia.

\section{Achalasia}

EC develop in $3 \%$ to $7 \%$ of patients with achalasia, which is significantly higher than in the healthy population. Recent results indicate a 10 times higher risk of developing ESCC and EAC in patients with achalasia. Corrosive constrictions increase the risk of developing ESCC by about 1000 times (50).

\section{Tylosis}

Genetic defect in the $17 q 25$ region, characterized by hyperkeratosis of the palms and soles, is associated with a high risk of developing ESCC after 65 years of age ( 51$)$. 


\section{Plummer Vinson syndrome}

PVS is also associated with increased risk of developing esophageal cancer (52).

\section{Exposure to harmful substances}

Various studies have indicated that exposure to asbestos may increase the risk of developing EC 2 to 16 times. The IARC has classified asbestos and silicon in the group of human carcinogens (Group 1 carcinogens), mostly because of their effect on lung cancer and mesothelioma (53).

\section{Low socio-economic status}

A large number of epidemiological studies have confirmed that the risk of developing ESCC is higher in populations with lower socioeconomic status (SES) (13). Higher tobacco and alcohol use or poor nutrition among people with lower SES are responsible for increased risk. Less data is available for EAC (54). Recent studies have indicated that SES is inversely associated with EAC as well, but one study found no association (55).

Population attributable risk (PAR) is defined as the proportion of disease in a population that can be attributed to a particular risk factor.

About $78.7 \%$ (95\% CI 66.5\%-87.3\%) EAC compared to $89.4 \%$ ESCC cases can be attributed to one or more well-defined risk factors, of which smoking, alcohol, body mass index and GERD contribute the most (Table 2) (56).

Table 2. Population attributable risk for esophageal adenocarcinoma (EAC) and esophageal squamous cell carcinoma (ESCC)

\begin{tabular}{||l|c|}
\hline \multicolumn{1}{|c|}{ Risk factor } & PAR-EAC \\
\hline \hline Smoking Risk factor & $39.7 \%$ \\
\hline BMI & $41.1 \%$ \\
\hline GERD & $29.7 \%$ \\
\hline Low fruit and vegetable intake & $15.3 \%$ \\
\hline Combined PAR & $78.7 \%$ \\
\hline \hline \multicolumn{1}{|c|}{ PAR-ESCC } \\
\hline \hline Smoking & $56.9 \%$ \\
\hline Alcohol & $72.4 \%$ \\
\hline Low fruit and vegetable intake & $28.7 \%$ \\
\hline Combined PAR & $89.4 \%$ \\
\hline
\end{tabular}

$\begin{array}{llll}\text { Antioxidants } & \text { Control Risk Ratio } & \text { Risk Ratio }\end{array}$

\begin{tabular}{|c|c|c|c|c|c|c|c|}
\hline Study or Subgroup & Events & Total & Events & Total & \multirow[t]{2}{*}{ Weight } & M-H, Random, $95 \% \mathrm{Cl}$ & M-H, Random, $95 \% \mathrm{Cl}$ \\
\hline \multicolumn{6}{|c|}{ Occurrence of esophageal cancer } & & \\
\hline ATBC 2003 & 47 & 21846 & 13 & 7287 & $8.8 \%$ & $1.21[0.65,2.23]$ & \\
\hline CARET 2004 & 44 & 9420 & 29 & 8894 & $15.1 \%$ & $1.43[0.90,2.29]$ & -- \\
\hline HPS 2002 & 31 & 10269 & 26 & 10267 & $12.2 \%$ & $1.19[0.71,2.01]$ & \\
\hline Munoz 1985 & 4 & 305 & 3 & 305 & $1.5 \%$ & $1.33[0.30,5.91]$ & \\
\hline NIT2 1993 & 123 & 1657 & 128 & 1661 & $58.5 \%$ & $0.96[0.76,1.22]$ & \\
\hline NPCT 1996 & 2 & 653 & 5 & 659 & $1.2 \%$ & $0.40[0.08,2.07]$ & \\
\hline SUVIMAX 2004 & 2 & 6481 & 2 & 6536 & $0.9 \%$ & $1.01[0.14,7.16]$ & \\
\hline WHS 2005 & 4 & 19937 & 3 & 19939 & $1.5 \%$ & $1.33[0.30,5.96]$ & \\
\hline $\begin{array}{l}\text { Zhu } 2003 \\
\text { Subtotal }(95 \% \mathrm{Cl})\end{array}$ & 0 & $\begin{array}{r}118 \\
70686\end{array}$ & 1 & $\begin{array}{r}54 \\
55602\end{array}$ & $\begin{array}{r}0.3 \% \\
100.0 \%\end{array}$ & $\begin{array}{l}0.15[0.01,3.72] \\
\mathbf{1 . 0 6}[0.89, \mathbf{1 . 2 8}]\end{array}$ & \\
\hline $\begin{array}{l}\text { Total events } \\
\text { Heterogeneity: Tau²= } \\
\text { Test for overall effect: }\end{array}$ & $\begin{array}{r}257 \\
0.00 ; \text { Chi } \\
Z=0.66\end{array}$ & $\begin{array}{l}P=5.51 \\
P=0.51\end{array}$ & $\begin{array}{r}210 \\
d f=8(P\end{array}$ & $=0.70)$ & $=0 \%$ & & \\
\hline
\end{tabular}

Figure 1. Occurrence of esophageal cancer after supplementation with antioxidants 


\section{Prevention}

Prevention of esophageal cancer can be divided into primary and secondary.

\section{Primary}

Primary prevention consists of lifestyle changes that reduce the prevalence of known risk factors like smoking cessation, stopping of alcohol consumption and increased intake of fruits and vegetables (57).

\section{Secondary}

Secondary prevention consists of chemoprevention (use of specific natural or synthetic chemical agents to reverse, suppress, or prevent the progression of precancerous conditions to invasive cancer), screening and monitoring program (58).

\section{Pharmacological chemoprevention}

\section{Antioxidant supplements}

Antioxidants protect against oxidative stress involved in the pathogenesis of many diseases including esophageal cancer. Antioxidant supplements containing beta-carotene, vitamins A, C, E, and selenium have no effect on the incidence of EC (Figure 1) (30).

\section{NSAIDs, aspirin}

A systematic review and meta-analysis of 9 studies concluded that aspirin and other NSAIDs reduce the risk of $\mathrm{EC}$ in a dose-response manner (59). Phase III RCT (AspECT trial: Aspirin Esomeprazole Chemoprevention Trial) evaluated the beneficial and harmful effects of the combination of aspirin and esomeprazole for EC prevention (60). Highdose PPI and aspirin significantly improved outcomes in patients with Barrett's esophagus (60). One RCT in which high doses of IPP were tested in order to suppress acid secretion and reduce $\mathrm{BE}$ showed a small but statistically significant regression of BE after elimination of reflux symptoms, which was confirmed by $\mathrm{pH}$ monitoring and recording of subjective symptoms.

\section{Screening - EAC}

Screening of patients with BE is still controversial given the lack of evidence that screening has the effect on reducing mortality from EAC (61). The annual rate of neoplastic transformation of $B E$ is $0.5 \%$ (61). Standard endoscopy with biopsy is the most reliable in diagnosing BE. There are several limitations of screening like low negative predictive significance, risk, discomfort and cost (Figure 2).

\section{Supervision - EAC}

Endoscopic supervision is recommended due to the association of $\mathrm{BE}$ with EAC, slow progression of $B E$ through dysplasia to $E A C$, increasing incidence of EAC, poor prognosis of EAC when detected in the symptomatic phase, and better prognosis after treatment of dysplasia/neoplasia detected by monitoring (Figure 3) (61).

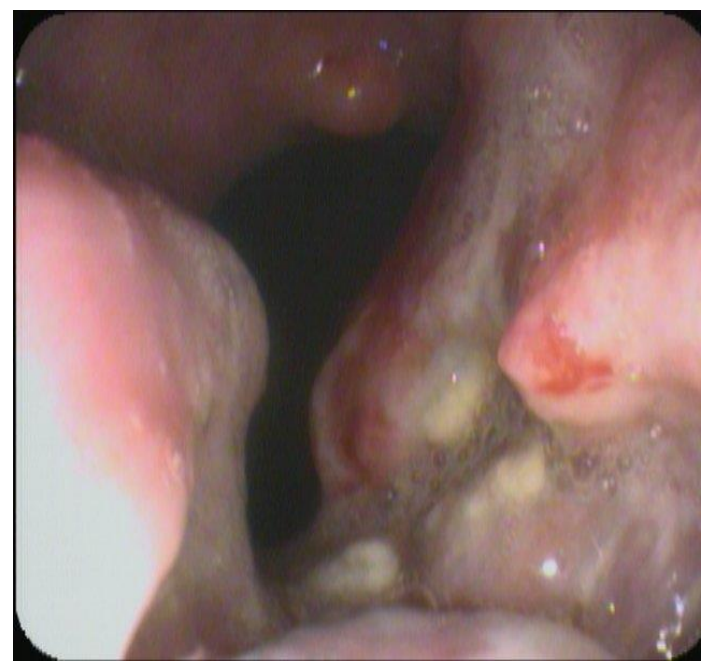

Figure 3. Esophageal cancer

Figure 2. Barrett's esophagus 


\section{Conclusion}

Esophageal cancer is a very aggressive and common cancer in the world. Although ESCC and EAC differ in histology and geographic distribution, many of their risk factors and carcinogenetic mechanisms are identical. The most common risk factor for developing EAC is Barrett's esophagus. The most important risk factors for developing ESCC are tobacco, alcohol, and a diet poor in fruits and vegetables. Elimination of risk factors responsible for the development of esophageal cancer can result in reduced incidence and mortality rates.
1. Brewer LA. History of surgery of the esophagus. The American Journal of Surgery 1980;139(6):730-43. [CrossRef] [PubMed]

2. Karamanou M MK, Papaioannou TG, Zografos G, Androutsos G. Hallmarks in history of esophageal carcinoma JBUON 2017;22(4):1088-91. [PubMed]

3. Umar SB FD. Esophageal cancer: Epidemiology, pathogenesis and prevention. Nature Clinical Practice Gastroenterology and Hepatology 2008;5(9):517-26. [CrossRef] [PubMed]

4. Ferlay J, Shin H-R, Bray F, Forman D, Mathers C, Parkin DM. Estimates of worldwide burden of cancer in 2008: GLOBOCAN 2008. International Journal of Cancer 2010;127(12):2893-17. [CrossRef] [PubMed]

5. Kamangar F, Chow W-H, C. Abnet C, M. Dawsey S. Environmental causes of esophageal cancer. Gastroenterology Clinics of North America 2009;38(1):2757. [CrossRef] [PubMed]

6. Lambert R, Hainaut P. Esophageal cancer: The precursors (Part II). Endoscopy 2007;39(07):659-64. [CrossRef] [PubMed]

7. Lambert R, Hainaut P. Esophageal cancer: Cases and causes (Part I). Endoscopy 2007;39(06):550-5. [CrossRef] [PubMed]

8. Eslick GD. Esophageal cancer: a historical perspective. Gastroenterology Clinics of North America 2009;38 (1):1-15. [CrossRef] [PubMed]

9. Kamangar F, Dores GM, Anderson WF. Patterns of cancer incidence, mortality, and prevalence across five continents: defining priorities to reduce cancer disparities in different geographic regions of the world. Journal of Clinical Oncology 2006;24(14):2137-50. [CrossRef] [PubMed]

10. Enzinger PC, Mayer RJ. Esophageal cancer. New England Journal of Medicine 2003;349(23):2241-52. [CrossRef] [PubMed]
11. Ho ALK, Smyth EC. A global perspective on esophageal cancer: two diseases in one. The Lancet Gastroenterology \& Hepatology 2020;5(6):521-2. [CrossRef] [PubMed]

12. Kamangar F, Nasrollahzadeh D, Safiri S, Sepanlou SG, Fitzmaurice C, Ikuta KS, et al. The global, regional, and national burden of oesophageal cancer and its attributable risk factors in 195 countries and territories, 1990\&\#x2013;2017: a systematic analysis for the Global Burden of Disease Study 2017. The Lancet Gastroenterology \& Hepatology 2020;5(6):582-97. [CrossRef] [PubMed]

13. Abnet CC, Arnold M, Wei W-Q. Epidemiology of esophageal squamous cell carcinoma. Gastroenterology 2018;154(2):360-73. [CrossRef] [PubMed]

14. Craver LF. A clinical study of etiology of gastric and esophageal carcinoma. The American Journal of Cancer 1932;16(1):68-102.

15. Watson WL. Cancer of the esophagus: some etiological considerations. Am J Roentgenol 1939;41(3): 420-4.

16. Freedman ND, Abnet CC, Leitzmann MF, Mouw T, Subar AF, Hollenbeck AR, et al. A prospective study of tobacco, alcohol, and the risk of esophageal and gastric cancer subtypes. American Journal of Epidemiology 2007;165(12):1424-33. [CrossRef] [PubMed]

17. Morris Brown L, Hoover $R$, Silverman D, Baris D, Hayes R, Swanson GM, et al. Excess incidence of squamous cell esophageal cancer among US black men: role of social class and other risk factors. American Journal of Epidemiology 2001;153(2):11422. [CrossRef] [PubMed]

18. Wu AH, Wan P, Bernstein L. A multiethnic populationbased study of smoking, alcohol and body size and risk of adenocarcinomas of the stomach and esophagus (United States). Cancer Causes \& Control 2001;12(8):721-32. [CrossRef] [PubMed] 
19. Gammon MD, Ahsan $H$, Schoenberg JB, West AB, Rotterdam $\mathrm{H}$, Niwa $\mathrm{S}$, et al. Tobacco, alcohol, and socioeconomic status and adenocarcinomas of the esophagus and gastric cardia. JNCI: Journal of the National Cancer Institute 1997;89(17):1277-84. [CrossRef] [PubMed]

20. International Agency for Research on Cancer. IARC working group on the evaluation of carcinogenic risks to humans. Coffee, tea, mate, methylxanthines and Methylglyoxal. Lyon (FR): International Agency for Research on Cancer; 1991. "cited 2021 december 21"; Available from: https://www.ncbi.nlm.nih.gov/books/NBK507026/

21. Muñoz N, Victora CG, Crespi M, Saul C, Braga NM, Correa $\mathrm{P}$. Hot maté drinking and precancerous lesions of the oesophagus: An endoscopic survey in southern brazil. International Journal of Cancer 1987;39(6): 708-9. [CrossRef] [PubMed]

22. Sewram V, De Stefani E, Brennan P, Boffetta P. Maté consumption and the risk of squamous cell esophageal cancer in Uruguay. Cancer Epidemiology Biomarkers \&amp; Prevention 2003;12(6):508-13. [PubMed]

23. Yang CS, Chen XL. Research on esophageal cancer: With personal perspectives from studies in China and Kenya. International Journal of Cancer 2021;149(2): 264-276. [PubMed]

24. International Agency for Research on Cancer. IARC working group on the evaluation of carcinogenic risks to humans. Some Naturally Occurring Substances: Food Items and Constituents, Heterocyclic Aromatic Amines and Mycotoxins IARC Monographs on the Evaluation of Carcinogenic Risks to Humans. "cited 2021 december 21"; Available from: https://www.ncbi.nlm.nih.gov/books/NBK513574/

25. Vingeliene S, Chan DSM, Aune D, Vieira AR, Polemiti E, Stevens C, et al. An update of the WCRF/AICR systematic literature review on esophageal and gastric cancers and citrus fruits intake. Cancer Causes \& Control 2016;27(7):837-51. [CrossRef] [PubMed]

26. González CA, Pera G, Agudo A, Bueno-de-Mesquita $H B$, Ceroti $M$, Boeing $H$, et al. Fruit and vegetable intake and the risk of stomach and oesophagus adenocarcinoma in the European Prospective Investigation into Cancer and Nutrition (EPIC-EURGAST). International Journal of Cancer 2006;118(10):255966. [CrossRef] [PubMed]

27. Yamaji T, Inoue $M$, Sasazuki S, Iwasaki M, Kurahashi $\mathrm{N}$, Shimazu $\mathrm{T}$, et al. Fruit and vegetable consumption and squamous cell carcinoma of the esophagus in Japan: The JPHC study. International Journal of Cancer 2008;123(8):1935-40. [CrossRef] [PubMed]

28. Blot WJ, Li J-Y, Taylor PR, Guo W, Dawsey S, Wang G$Q$, et al. Nutrition Intervention Trials in Linxian, China: Supplementation with specific vitamin/mineral combinations, cancer incidence, and disease-specific mortality in the general population. Journal of the National Cancer Institute 1993;85(18):1483-91. [CrossRef] [PubMed]

29. Li J-Y, Taylor PR, Li B, Dawsey S, Wang G-Q, Ershow $A G$, et al. Nutrition Intervention Trials in Linxian, China: Multiple vitamin/mineral supplementation, cancer incidence, and disease-specific mortality among adults with esophageal dysplasia. Journal of the National Cancer Institute 1993;85(18):1492-8. [CrossRef] [PubMed]

30. Bjelakovic G, Nikolova D, Simonetti RG, Gluud C. Antioxidant supplements for preventing gastrointestinal cancers. Cochrane Database of Systematic Reviews 2008;3:CD004183. [CrossRef] [PubMed]

31. Lagergren J, Bergstrom R, Adami HO, Nyren $\mathrm{O}$. Association between medications that relax the lower esophageal sphincter and risk for esophageal adenocarcinoma. Annals of Internal Medicine 2000; 133(3):165-75. [CrossRef] [PubMed]

32. Vaughan TL, Farrow DC, Hansten PD, Chow WH, Gammon MD, Risch HA, et al. Risk of esophageal and gastric adenocarcinomas in relation to use of calcium channel blockers, asthma drugs, and other medications that promote gastroesophageal reflux. Cancer Epidemiology Biomarkers \&amp; Prevention 1998; 7(9):749-56. [PubMed]

33. Farrow DC, Vaughan TL, Sweeney C, Gammon MD, Chow W-H, Risch HA, et al. Gastroesophageal reflux disease, use of $\mathrm{H} 2$ receptor antagonists, and risk of esophageal and gastric cancer. Cancer Causes \& Control 2000;11(3):231-8. [CrossRef] [PubMed]

34. Islami F, Ren JS, Taylor PR, Kamangar F. Pickled vegetables and the risk of oesophageal cancer: a meta-analysis. British Journal of Cancer 2009;101(9): 1641-7. [CrossRef] [PubMed]

35. Rokkas T, Pistiolas D, Sechopoulos P, Robotis I, Margantinis G. Relationship between Helicobacter pylori infection and esophageal neoplasia: a metaanalysis. Clinical Gastroenterology and Hepatology 2007;5(12):1413-7. [CrossRef] [PubMed]

36. Zhuo $X$, Zhang $Y$, Wang $Y$, Zhuo $W$, Zhu $Y$, Zhang $X$. Helicobacter pylori infection and oesophageal cancer risk: association studies via evidence-based metaanalyses. Clinical Oncology 2008;20(10):757-62. [CrossRef] [PubMed]

37. Wang Z, Shaheen NJ, Whiteman DC, Anderson LA, Vaughan TL, Corley DA, et al. Helicobacter pylori infection is associated with reduced risk of Barrett's esophagus: an analysis of the Barrett's and esophageal adenocarcinoma consortium. Official journal of the American College of Gastroenterology 2018; 113(8):1148-55. [CrossRef] [PubMed]

38. WHO. IARC working group on the evaluation of carcinogenic risks to humans. Human papilloma viruses IARC Monographs on the Evaluation of Carcinogenic Risks to Humans. Lyon;2007.

39. Zhang M, Wang J, Zhao Q, Mishra V, Fan J, Sun Y. Polycyclic aromatic hydrocarbons (PAHs) and esophageal carcinoma in Handan-Xingtai district, North China: a preliminary study based on cancer risk assessment. Environmental Monitoring and Assessment 2020;192(9):596. [CrossRef] [PubMed]

40. Huang Y, Cao D, Chen Z, Chen B, Li J, Guo J, et al. Red and processed meat consumption and cancer outcomes: Umbrella review. Food Chemistry 2021; 356:129697. [CrossRef] [PubMed]

41. International Agency for Research on Cancer. IARC working group on the evaluation of carcinogenic risks to humans. Re-evaluation of Some Organic Chemicals, Hydrazine and Hydrogen Peroxide. IARC Monographs on the Evaluation of Carcinogenic Risks to Humans. "cited 2021 december 21"; Available from: from: https://www.ncbi.nlm.nih.gov/books/NBK498701/. [CrossRef][PubMed]

42. Jotamo C, Edgar C, Rita F, José MCdC, Carla C, Lúcio LS. Esophageal cancer in Mozambique: should mycotoxins be a concern? PAMJ 2019;33:187. [CrossRef] [PubMed]

43. Lagergren J, Bergström R, Lindgren A, Nyrén $O$. Symptomatic gastroesophageal reflux as a risk factor for esophageal adenocarcinoma. New England Journal of Medicine 1999;340(11):825-31. [CrossRef] [PubMed]

44. Cossentino MJ, Wong R. Barrett's esophagus and risk of esophageal adenocarcinoma. Semin Gastrointest Dis 2003;14(3):128-35. [PubMed]

45. Turati F, Tramacere I, La Vecchia C, Negri E. A metaanalysis of body mass index and esophageal and 
gastric cardia adenocarcinoma. Annals of Oncology 2013;24(3):609-17. [CrossRef] [PubMed]

46. Corley DA KA. Body mass index and gastroesophageal reflux disease: a systematic review and meta-analysis. Am J Gastroenterol 2006;101(11):2619-28. [CrossRef] [PubMed]

47. Bu X, Ma Y, Der R, Demeester T, Bernstein L, Chandrasoma PT. Body mass index is associated with Barrett esophagus and cardiac mucosal metaplasia. Digestive Diseases and Sciences 2006;51(9):1589-94. [CrossRef] [PubMed]

48. Smith M, Zhou M, Whitlock G, Yang G, Offer A, Hui G, et al. Esophageal cancer and body mass index: Results from a prospective study of 220,000 men in China and a meta-analysis of published studies. International Journal of Cancer 2008;122(7):1604-10. [CrossRef] [PubMed]

49. Wu AH, Tseng C-C, Bernstein L. Hiatal hernia, reflux symptoms, body size, and risk of esophageal and gastric adenocarcinoma. Cancer 2003;98(5):940-8. [CrossRef] [PubMed]

50. Brücher BLDM, Stein $H J$, Bartels $H$, Feussner $H$, Siewert JR. Achalasia and esophageal cancer: incidence, prevalence, and prognosis. World Journal of Surgery 2001;25(6):745-9. [CrossRef] [PubMed]

51. Risk JM, Mills HS, Garde J, Dunn JR, Evans KE, Hollstein M, et al. The tylosis esophageal cancer (Toc) locus: more than just a familial cancer gene. Diseases of the Esophagus 1999;12(3):173-6. [CrossRef] [PubMed]

52. Sid'Ahmed L BA, Aye M, Alhousseini Ag M. Un cancer pharyngo-oesophagien chez un patient atteint du syndrome de Plummer Vinson (A propos d'un cas) $[A$ pharyngo-esophageal cancer in a patient with Plummer Vinson syndrome (Apropos of a case). Mali Med 2010;25(2):56-7. [PubMed]

53. Cancer IAfRo. IARC working group on the evaluation of carcinogenic risks to humans. Silica and some silicates $1987 ; 42$.
54. Brewster DH, Fraser LA, McKinney PA, Black RJ. Socioeconomic status and risk of adenocarcinoma of the oesophagus and cancer of the gastric cardia in Scotland. British Journal of Cancer 2000;83(3):38790. [CrossRef] [PubMed]

55. Jansson C, Johansson ALV, Nyrén O, Lagergren J. Socioeconomic factors and risk of esophageal adenocarcinoma: A nationwide Swedish case-control study. Cancer Epidemiology Biomarkers \& Prevention 2005; 14(7):1754-61. [CrossRef] [PubMed]

56. Engel LS, Chow WH, Vaughan TL, Gammon MD, Risch $\mathrm{HA}$, Stanford JL, et al. Population attributable risks of esophageal and gastric cancers. JNCI: Journal of the National Cancer Institute 2003;95(18):1404-13. [CrossRef] [PubMed]

57. Abnet CC, Corley DA, Freedman ND, Kamangar F. Diet and upper gastrointestinal malignancies. Gastroenterology 2015;148(6):1234-43. [CrossRef] [PubMed]

58. Chung C-S, Lee Y-C, Wu M-S. Prevention strategies for esophageal cancer: Perspectives of the East vs. West. Best Practice \& Research Clinical Gastroenterology 2015;29(6):869-83. [CrossRef] [PubMed]

59. Corley DA, Kerlikowske $K$, Verma $R$, Buffler $P$. Protective association of aspirin/NSAIDs and esophageal cancer: A systematic review and meta-analysis. Gastroenterology 2003;124(1):47-56.

[CrossRef] [PubMed]

60. Jankowski JAZ, de Caestecker J, Love SB, Reilly G, Watson P, Sanders S, et al. Esomeprazole and aspirin in Barrett's oesophagus (AspECT): a randomised factorial trial. The Lancet 2018;392(10145):400-8. [CrossRef] [PubMed]

61. Triggs JR, Falk GW. Best practices in surveillance for Barrett's esophagus. Gastrointestinal Endoscopy Clinics of North America 2021;31(1):59-75. [CrossRef] [PubMed] 


\title{
EPIDEMIOLOGIJA RAKA JEDNJAKA, FAKTORI RIZIKA I MOGUĆNOSTI PREVENCIJE
}

\author{
Milica Bjelaković ${ }^{1}$ Daniela Benedeto Stojanov ${ }^{1}$, Ivana Golubović2 \\ Marko Bjelaković3 ${ }^{3}$ Marko Gmijović 4
}

\begin{abstract}
${ }^{1}$ Univerzitetski klinički centar Niš, Klinika za gastroenterologiju i hepatologiju, Niš, Srbija ${ }^{2}$ Univerzitetski klinički centar Niš, Klinika za hematologiju i kliničku imunologiju, Niš, Srbija ${ }^{3}$ Univerzitetski klinički centar Niš, Klinika za pulmologiju, Nišs, Srbija

${ }^{4}$ Univerzitetski klinički centar Niš, Klinika za digestivnu hirurgiju, Niš, Srbija
\end{abstract}

Kontakt: Milica Bjelaković

Bulevar dr Zorana Đinđića 48, 18000 Niš, Srbija

E-mail: milicabj@icloud.com

Incidencija raka jednjaka i mortalitet izazvan rakom jednjaka u razvijenim zemljama porasli su u poslednje četiri decenije, za razliku od smanjene incidencije i mortaliteta kod drugih karcinoma. Rak jednjaka je osmi najčešći karcinom i šesti vodeći uzrok smrti od raka u svetu. U poslednje 3 decenije došlo je do promene vodećeg histološkog tipa karcinoma jednjaka, u razvijenim zemljama, sa skvamoznih ćelija jednjaka na adenokarcinom jednjaka. Faktori rizika dovode do pojave prekanceroznih stanja, skvamozne displazije, kao prekursora skvamoznog karcinoma jednjaka i Baretovog jednjaka, kao prekursora adenokarcinoma jednjaka. Duvan, alkohol, topli Mate napitak i kiselo povrće povezuju se sa povećanim rizikom od raka jednjaka, dok bi povećan unos voća i povrća mogao preventivno da utiče na rak jednjaka. Dokazi o uticaju relaksansa distalnog ezofagealnog sfinktera i antagonista histamin 2 receptora su kontradiktorni. Postoji inverzna povezanost infekcije Helicobacter pilori i Baretovog jednjaka i adenokarcinoma jednjaka. Imamo nisku sigurnost dokaza o uticaju infekcije humanim papiloma virusom i različitim hemijskim kancerogenima, kao što su policiklični aromatični ugljovodonici, N-nitrozo jedinjenja, acetaldehid i fumonizini na rak jednjaka. Brojni predisponirajući uslovi, kao što su gastroezofagealna refluksna bolest, Baretov jednjak, gojaznost, hijatalna hernija, ahalazija, tiloza i Plummer Vinsonov sindrom mogu povećati rizik od raka jednjaka. Primarna prevencija raka jednjaka sastoji se od promene načina života, koje obuhvataju prestanak pušenja, prestanak konzumiranja alkohola i povećan unos voća i povrća. Sekundarna prevencija sastoji se od hemoprevencije, skrininga i programa praćenja.

Acta Medica Medianae 2021;60(4):72-81.

Ključne reči: rak jednjaka, rizik, prevencija 